\title{
Integrasi Etnopedagogi dalam Mengembangkan Model Pembelajaran Biologi
}

\author{
Iwan Setia Kurniawan $^{1 *}$, Rifki Survani ${ }^{2}$ \\ ${ }^{12}$ Universitas Pasundan Bandung \\ ఏ-mail: iwansetiakurniawan@yahoo.com
}

\begin{abstract}
Abstrack
Model of learning is a syntax or learning steps depicted from the beginning to the end presented in full or typical in the learning process. This study aims to determine the ability of biology pre-service teacher in developing biology learning model integrated ethno pedagogy. This research is a quantitative descriptive research, data obtained based on the results of data analysis is described to obtain information or description of the results of this study. Population in this study as many as 164 students are divided into 38 groups. Technique of data collecting with non-test, data obtained from document of assignment of student report given score based on its indicator which divided into some aspect of assessment and student response questionnaire. The results showed that the ability of biology pre-service teacher in developing the learning model oriented ethno pedagogy including sufficient category with an average score of 75. Students' response to development of learning model oriented ethno pedagogy is good, $70.04 \%$ of students expected. Thus it can be concluded that the ability of students in developing biology learning model integrated ethno pedagogy still needs to be developed especially for several aspects. The results of this study can be used as a reference for the lecture program in the future.
\end{abstract}

Keyword: ethno pedagogy, learning model, development of learning model, biology learning

Copyright (C) 2018 IICET (Indonesia) - All Rights Reserved

Indonesian Institute for Counseling, Education and Therapy (IICET)

\section{PENDAHULUAN}

Model pembelajaran merupakan sebuah sintaks atau langkah-langkah pembelajaran yang tergambar dari awal sampai akhir yang disajikan secara utuh atau khas dalam proses pembelajaran. Dengan kata lain, model pembelajaran merupakan rangkaian satu kesatuan yang utuh antara pendekatan, strategi, metode, dan teknik. Model pembelajaran diibaratkan sebuah kerangka yang menggambarkan prosedur yang sistematis dalam mengorganisasi pengalaman belajar peserta didik untuk mencapai tujuan belajar tertentu, dan berfungsi sebagai pedoman bagi perancang pembelajaran dan guru dalam merencanakan dan melaksanakan aktivitas belajar mengajar. Model pembelajaran merupakan deskripsi dari lingkungan belajar yang menggambarkan perencanaan dan kerangka untuk merancang pembelajaran untuk mengatasi kesulitan guru (Joyce dan Weil, 2000; Rustaman, 2005; Arikunto, 2003; Dahar, 1989). Inilah tugas berat seorang guru dimana guru selain harus memiliki kompetensi yang handal, juga harus membentuk individu siswa yang kompetitif, kreatif, dan berkarakter pada jaman serba canggih ini. Dapat dipastikan bahwa hanya individu 
yang mampu bersaing yang akan berbicara dalam era globalisasi, untuk itu setiap individu harus memiliki kompetensi yang handal dalam berbagai bidang sesuai dengan minat, bakat dan kemampuan nyata seiring dengan kemajuan ilmu pengetahuan dan teknologi (Sanjaya, 2005; Sa'ud, 2008). Kegiatan pembelajaran dikelas tidak terlepas dari model pembelajaran. ketepatan memilih model pembejaran untuk materi tertentu akan berdampak baik pada siswa. Penggunaan model pembelajaran harus menjadi aspek kunci dalam kegiatan pembelajaran dan implikasinya dalam pendidikan terutama oleh calon guru (Krell, et al., 2015; Cil, et al., 2016). Kemajuan ilmu pengetahuan dan teknologi, khususnya menyangkut dengan teori pembelajaran telah banyak mendorong dan mengilhami terhadap inovasi di bidang model-model pembelajaran menggunakan teknologi (Saud, 2008; Zaltman, 1973) teknologi dapat mendukung motivasi lebih dan mendorong program pendidikan dan meningkatkan metode pengajaran jika dirancang sedemikian rupa sehingga dapat mencapai tujuan pembelajaran (Costa, et al; Marsh, 1996; Eggen dan Kauchak (2012).

Biologi merupakan cabang ilmu pengetahuan alam yang mempelajari tentang mahluk hidup khususnya manusia, hewan dan tumbuhan dan interaksinya dengan lingkungan yang dibangun atas konsepkonsep yang dilandasi pada fakta-fakta yang dapat diindera melalui proses metode ilmiah (Rustaman, 2005; Prawoto, 1992). Ilmu biologi mempelajarai banyak hal mengenai mahluk hidup dan interaksinya dengan lingkungan. Kompleksitas ilmu biologi menjadi sebuah kendala dalam mempelajari ilmu biologi terutama konsep-konsep yang bersipat abstrak. Biologi berkaiatan dengan cara mencari tahu tentang alam secara sistematis, sehingga pembelajaran biologi bukan hanya penguasaan kumpulan-kumpulan pengetahuan yang berupa fakta-fakta, konsep atau prinsip-prinsip saja tetapi juga merupakan suatu proses penemuan. Sehubungan dengan itu, pembelajaran biologi menekankan pada pemberian pengalaman langsung untuk mengembangkan kompetensi agar peserta didik menjelajahi dan memahami alam sekitar secara ilmiah. Dalam teori modern, proses pembelajaran tidak tergantung sekali kepada keberadaan guru (pendidik) sebagai pengelola proses pembelajaran. Hal ini didasarkan bahwa proses belajar pada hakikatnya merupakan interaksi antar siswa dengan obyek yang dipelajari (Mudjiman, 2009).

Tuntutan guru pada masa sekarang ini harus memiliki tanggung jawab membangun karakter bangsa dan budaya. Dalam hal ini etnopedagogi memiliki peranan penting. Etnopedagogi memandang pengetahuan atau kearifan lokal (local knowledge, local wisdom) sebagai sumber inovasi dan keterampilan yang dapat diberdayakan untuk kesejahteraan masyarakat. Etnopedagogi adalah praktek pendidikan berbasis kearifan lokal dalam berbagai ranah seperti pengobatan, seni bela diri, lingkungan hidup, pertanian, ekonomi, pemerintahan, sistem penanggalan dan lain-lain.Kearifan lokal layak menjadi basis pendidikan dan pembudayaan. Pengenalan terhadap budaya lokal khususnya di Jawabarat kepada siswa sangat diperlukan sehingga siswa dapat menghayati, melestarikan budayanya dan dirinya sendiri. Pengembangan model pembelajaran biologi yang berorientasi pada etnopedagogi diharapkan dapat memberikan pengayaan yang berarti dalam menunjang tujuan pendidikan nasional yang akan membentuk karakter bangsa. Oleh karena itu, etnopedagogi menjadi landasan dalam pengembangan model pembelajaran biologi yang berbasis kearifan lokal, karena pembelajaran tersebut dapat mendekatkan guru dan siswa dengan situasi konkret yang mereka hadapi untuk dapat lebih memahami budayanya sendiri, sehingga menumbuhkan dan memberikan perhatian terhadap pemeliharaan dan pemanfaatan lingkungan alam sekitar (Suratno, 2010). Kebudayaan secara langsung ataupun tidak langsung, mampu memberikan identitas tertentu bagi individu dan masyarakat pendukungnya (Kosasih, t.t). Menurut Alwasilah et al. (Suratno, 2010) memandang Etnopedagogi sebagai praktik pendidikan berbasis kearifan local dalam berbagai ranah serta menekankan pengetahuan atau kearifan lokal sebagai sumber inovasi dan keterampilan yang dapat diberdayakan demi kesejahteraan masyarakat dimana kearifan lokal tersebut terkait dengan bagaimana pengetahuan dihasilkan, disimpan, diterapkan, dikelola dan diwariskan. Dalam hal ini, kearifan lokal memiliki ciri: 1) berdasarkan pengalaman; 2) teruji setelah digunakan berabad-abad; 3) dapat diadaptasikan dengan kultur kini; 4) padu dengan praktik keseharian masyarakat dan lembaga; 5) lazim dilakukan oleh individu maupun masyarakat; 6) bersifat dinamis; dan 7) sangat terkait dengan sistem kepercayaan.

\section{METODOLOGI}


Penelitian ini menggunakan metode kuantitatif dengan jenis penelitian deskriptif. Populasi pada penelitian ini adalah 164 mahasiswa yang terbagi dalam 38 kelompok. Teknik pengambilan sampel secara acak (ramdom sampling) berdasarkan rumus yang dikembangkan oleh Isaac dan Michael (Sugiyono, 2011) sebagai berikut:

$$
\begin{aligned}
& \text { Sampel }=\frac{\lambda^{2} \text { N.P.Q }}{d^{2}(N-1)+\lambda^{2} . P . Q} \\
& \lambda^{2}=\text { dengan } d k=1 . P=Q=0,5 . \quad d=0,005 . \quad N=\text { Jumlah populasi }
\end{aligned}
$$

Penelitian ini dilaksanakan pada bulan Maret 2017. Pengumpulan data dilakukan dengan teknik non tes. Teknik non tes untuk mengumpulkan data dilakukan dengan angket (kuesioner), pemeriksaaan dokumen (analisis dokumen) dan hasil penilaian guru terhadap model pembelajaran biologi yang dikembangkan. Angket berisi instrumen sikap mahasiswa terhadap pengembangan model pembelajaran biologi dengan etnopedagogi secara kualitatif. Kemudian data kualitatif dikonversi menjadi data kuantitatif. Angket berupa pernyataan sejumlah 20 butir pernyataan, 10 butir pernyataan positif dan 10 butir perenyataan negatif. Kuesioner yang digunakan dalam penelitian ini menggunakan skala Likert, dengan empat kategori yaitu sangat setuju (SS), setuju (S), tidak setuju (TS), dan sangat tidak setuju (STS). Untuk pernyataan yang bersifat positif kategori sangat setuju (SS) diberi skor 4, setuju (S) diberi skor 3, tidak setuju (TS) diberi skor 2, dan sangat tidak setuju (STS) diberi skor 1. Sedangkan pernyataan negatif, sangat setuju (SS) diberi skor 1, setuju (S) diberi skor 2, tidak setuju (TS) diberi skor 3, dan sangat tidak setuju (STS) diberi skor 4. Skor

\begin{tabular}{|c|c|c|}
\hline NO & ASPEK PENILAIAN & BOBOT SKOR \\
\hline 1 & Originalitas & 20 \\
\hline 2 & Keterterapan & 20 \\
\hline 3 & Sistematika Sintaks & 20 \\
\hline 4 & Integrasi Etnopedagogi & 20 \\
\hline 5 & Kreatifitas & 20 \\
\hline \multicolumn{2}{|c|}{ Jumlah Total } & 100 \\
\hline
\end{tabular}
tersebut nantinya akan dikonversi dan dideskripsikan berdasarkan hasil analisis dalam penelitian ini.

Tabel 1. Aspek Penilaian Laporan

Teknik analisis data yang digunakan adalah menggunakan analisis deskriptif kuantitatif. Analisis data kuantitaif dilakukan dengan teknik deskriptif yaitu analisis data statistik yang digunakan untuk menggambarkan data yang terkumpul sebagaimana adanya. Hasil analisis berupa penyajian data dalam bentuk tabel dan grafik. Dari data yang terkumpul pada penelitian selanjutnya dilakukan analisis dengan teknik analisis evaluasi secara deskriptif kuantitatif yaitu mendeskripsikan dan memaknai tiap-tiap komponen dibandingkan dengan acuan kriteria berdasarkan skor rerata ideal $(\mathrm{Mi})$ dan skor simpangan baku ideal (SBi) yang dicapai oleh lembar instrumen. Penelitian ini menggunakan angket skala 5 (lima) dengan konversi nilai dan skor, menentukan $(M i)$ dan $(S B i)$ pada penelitian ini menggunakan rumus yang dikembangkan oleh Jumadi (2012). Penentuan (Mi) dan (SBi) disajikan pada Tabel 2. 
Tabel 2. Konversi skor dalam skala 5

\begin{tabular}{ccc}
\hline Nilai & Skor & Kriteria \\
\hline $\mathbf{1}$ & $x>(M i+1,8 S B i)$ & Sangat baik \\
$\mathbf{2}$ & $(M i+0,6 S B i)<x<(M i+1,8 S B i)$ & Baik \\
$\mathbf{3}$ & $(M i-0,6 S B i)<x \leq(M i+0,6 S B i)$ & Cukup \\
$\mathbf{4}$ & $(M i-1,8 S B i)<x \leq(M i-0,6 S B i)$ & Kurang \\
$\mathbf{5}$ & $x \leq(M i-1,8 S B i)$ & Sangat kurang \\
\hline
\end{tabular}

\section{HASIL DAN PEMBAHASAN}

\section{Skor Rata-rata Kemampuan Kelompok Mahasiswa}

Data penelitian diperoleh dari setiap kelompok mahasiswa sebanyak 38 kelompok yang mendapatkan tugas untuk mengembangkan model pembelajaran biologi yang mengintegrasikan nilai-nilai kearifan lokal khususnya di tatar Pasundan (Sunda). Data hasil analisis berasal dari dokumen penugasan kepada kelompok mahasiswa yang dianalisis data berdasarkan beberapa aspek-aspeknya. Hasil analisis data dikonversi kedalam persen (\%). Untuk lebih jelasnya disajikan pada Gambar 1.

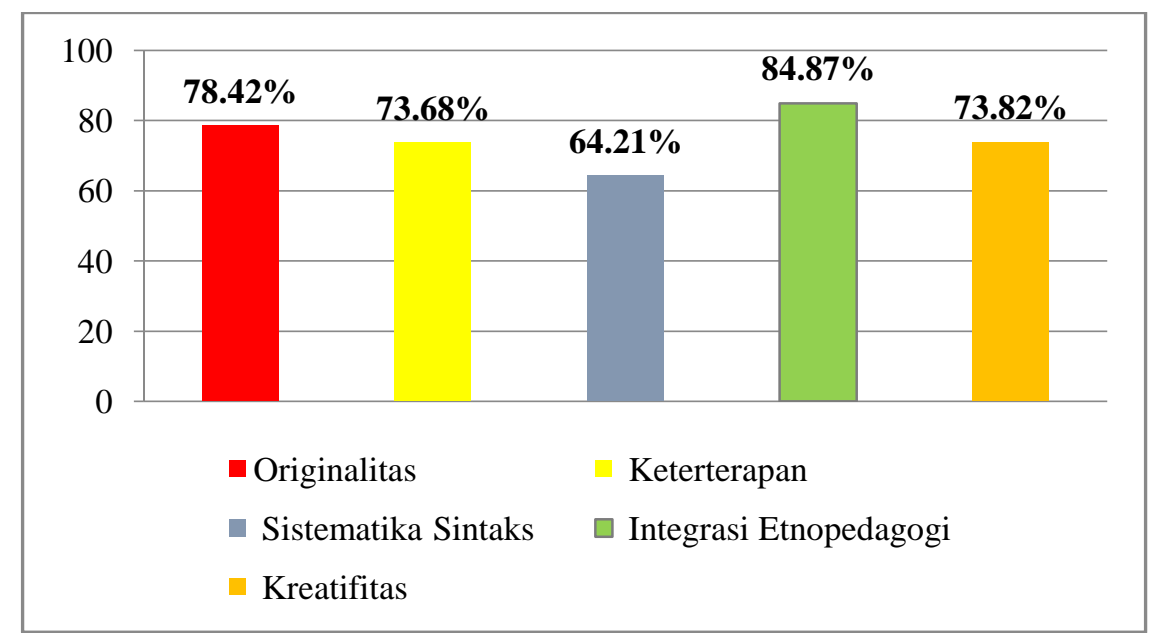

Gambar 1. Presentase Kemampuan Mahasiswa dalam Mengembangkan Model Pembelajaranberorientasi etnopedagogi

Berdasarkan Gambar 1. Aspek penilaian tertinggi yaitu pada integrasi etnopedagogi yang digunakan dalam mengembangkan model pembelajaran sebesar $84,87 \%$ dan aspek penilaian terendah pada sistematika sintaks pengembangan model pembelajaran sebesar 64,21\%. Berdasarkan aspek-aspek tersebut dapat dilihat kemampuan kelompok mahasiswa dalam mengembangkan model pembelajaran yang berorientasi etnopedagogi secara keseluruhan.

\section{Kriteria Kemampuan Mahasiswa}

Nilai rata-rata kemampuan kelompok mahasiswa diambil dari data hasil analisis penilaian tugas laporan pengembangan model pembelajaran biologi berorientasi etnopedagogi. Mengacu pada rumus yang dikembangkan oleh Jumadi (2012) nilai rata-rata siswa dapat diklasifikasikan berdasarkan kategorinya. Tiaptiap komponen dibandingkan dengan acuan kategori berdasarkan skor rerata ideal $(\mathrm{Mi})$ dan skor simpangan baku ideal (SBi) yang dicapai oleh lembar instrumen. Penelitian ini menggunakan angket skala 5 (lima) dengan konversi nilai dan skor. Untuk lebih jelasnya disajikan pada Tabel 3. 
Tabel 3. Konversi Skor

\begin{tabular}{|c|c|}
\hline SKOR & KRITERIA \\
\hline$x>78,8$ & Sangat Baik \\
\hline $75,6<x<78,8$ & Baik \\
\hline $72,4<x \leq 75,6$ & Cukup \\
\hline $69,2<x \leq 72,4$ & Kurang \\
\hline$x \leq 69,2$ & Sangat Kurang \\
\hline
\end{tabular}

Bedasarkan Tabel 3. nilai rata-rata kemampuan kelompok mahasiswa dalam mengembangkan model pembelajaran biologi berorientasi etnopedagogi sebesar 75 berada pada rentang 72,4-75,6 dengan demikan kemampuan mahasiswa dalam mengembangkan odel pembelajaran biologi berorientasi etnopedagogi termasuk kedalam kategori cukup.

\section{Kuesioner Tanggapan Mahasiswa}

Kuesioner tanggapan mahasiswa pada penelitian ini dianalisis dengan tujuan untuk memperoleh informasi bagaimana sikap atau respon mahasiswa terhadap pengembangan model pembelajaran berorientasi etnopedagogi. Pengambilan data dilakukan pada mahasiswa sebanyak 30 orang. Dengan menggunakan skala Likert data kualitatif dikonversi menjadi data kuantitatif. Skor data kuantitatif dikonversi ke dalam persen (\%), kemuadian dideskripsikan berdasarkan hasil analisis data. Deskripsi rekapitulasi data disajikan pada Tabel 4

Tabel 4. Deskripsi Tanggapan Mahasiswa Terhadap Pengembangan Model Pembelajaran Berorientasi Etnopedagogi

\begin{tabular}{cc}
\hline No Pernyatan & Presentase (\%) \\
\hline $\mathbf{1}$ & 86.67 \\
$\mathbf{3}$ & 80 \\
$\mathbf{4}$ & 75 \\
$\mathbf{5}$ & 75.83 \\
$\mathbf{6}$ & 78.33 \\
$\mathbf{7}$ & 77.5 \\
$\mathbf{8}$ & 72.5 \\
$\mathbf{9}$ & 73.33 \\
$\mathbf{1 0}$ & 65.83 \\
$\mathbf{1 1}$ & 66.67 \\
$\mathbf{1 2}$ & 63.33 \\
$\mathbf{1 3}$ & 61.67 \\
$\mathbf{1 4}$ & 57.5 \\
$\mathbf{1 5}$ & 62.5 \\
$\mathbf{1 6}$ & 60.83 \\
$\mathbf{1 7}$ & 65.83 \\
$\mathbf{1 8}$ & 64.17 \\
$\mathbf{1 9}$ & 70.83 \\
$\mathbf{2 0}$ & 68.33 \\
Rata-rata & 74.17 \\
& $\mathbf{7 0 , 0 4}$ \\
\hline
\end{tabular}


Berdasarkan Tabel 4. diperoleh informasi bahwa rata-rata persentase sikap mahasiswa sebesar 70.04\%. Hal ini menunjukan bahwa sebanyak 70,04\% mahasiswa merespon dengan baik pengembangan model pembelajaran biologi beroerientasi etnopedagogi dari yang diharapkan. Jika mengacu pada rumus yang dikembangkan oleh Sugiyono (2011:137), maka pada penelitian ini diperoleh skor ideal semua item sebesar 3800, sedangkan pada penelitian ini diperoleh skor sebesar 2850. Berdasarkan data tersebut maka tingkat persetujuean mahasiswa terhadap pengembangan model pembelajaran biologi sebesar $70.04 \%$ (diperoleh dari (3800:2850) x 100\%). Dengan demikian interval data respon mahasiswa dapat dideskripsikan pada Gambar 2.

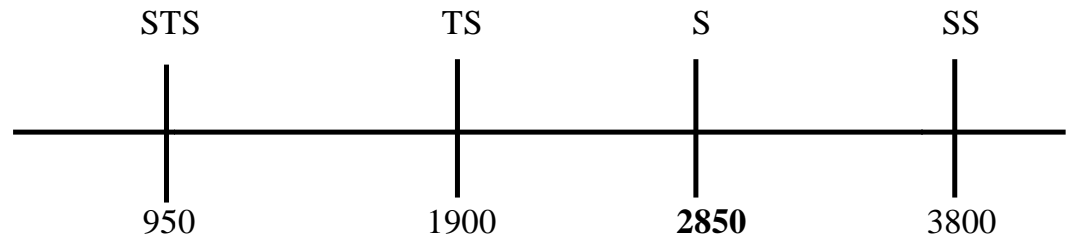

Gambar 4.2. Interval Data Respon Mahasiswa

Berdasarkan Gambar 2. diperoleh informasi bahwa dari 30 responden maka skor pada penelitian ini sebesar 2850 terletak tepat pada daerah setuju. Dengan demikian dapat kita peroleh informasi bahwa pada umumnya mahasiswa menyetujui dan merespon dengan baik adanya pengembangan model pembelajaran biologi berbasis etnopedagogi, adanya inovasi-inovasi dalam mengembangkan model pembelajaran khususnya pembelajaran biologi.

Model yang dikembangkan adalah model pembelajartan biologi yang berorientasi pada etnopedagogi khususnya budaya sunda yang menjadi jati diri di lingkungan Universitas Pasundan. Penelitian ini dilakukan pada mahasiswa semester tujuh (mahasiswa tingkat IV) Pendidikan Biologi, Fakultas Keguruan dan Ilmu Pendidikan. Pengembangan model ini mendorong salah satu misi universitas pasunda "Jembar Budayana" sehingga dalam pengembangannya kental dengan unsur budaya sunda. Kemampuan kelompok mahasiswa dalam mengembangkan model pembelajaran biologi berdasarkan aspek-aspeknya terbilang cukup baik dengan rata-rata diatas $60 \%$. Originalitas model yang dikembangkan oleh kelompok mahasiswa sebesar $78,42 \%$, hal ini menjelaskan bahwa model yang dikembangkan memiliki keaslian yang baik secara keseluruhan karena sebagian besar model yang dikembangkan oleh kelompok mahasiswa hasil pemikiran mereka yang belandaskan pada etnopedagogi (budaya sunda) bukan dari adopsi atau modifikasi model pembelajaran lain, hanya sebagian kecil kelompok mahasiswa yang mengadopsi dan modifikasi dari model pembelajaran lain. Hal ini sejalan dengan pendapat yang dikemukakan oleh Zaltman (1973) suatu inovasi dapat merupakan kombinasi dari bebagai atribut, bahkan inovasi dapat lahir karena hasil pemikiran murni sebagai akibat adanya kepentingan yang mendesak.

Keterterapan model pembelajaran yang dimaksud adalah sejauh mana model yang dikembangkan oleh mahasiswa dapat diterapkan (diimplementasikan) di dalam kelas hal ini dilihat dari hasil analisis model secara keseluruhan meliputi indikator, tujuan dan sintaks yang dikembangkan dalam pembelajaran. Keterterapan model yang dikembangkan termasuk kategori baik yaitu sebesar 73,68\%. Dengan demikian sebagian model yang dikembangkan oleh kelompok mahasiswa dapat diimplementasikan di dalam kelas dalam proses pembelajaran. Hal ini dapat dipahami karena mahasiswa sudah memiliki pengetahuan sebelumnya mengenai model pembelajaran pada mata kuliah lain. Sebagai hasilnya mahasiswa mampu merancang model pembelajaran dengan baik dan arah yang jelas sehingga tidak menutup kemungkinan model tersebut dapat diterapkan dalam pembelajaran di kelas. Hal ini didukung oleh pendapat yang dikemukakan oleh Rustaman (2000) model pembelajaran merupakan kerangka berpikir yang mengarahkan 
seorang merancang dan melaksanakan pembelajaran di kelas serta membimbing siswa belajar sehingga interaksi belajar mengajarnya menjadi lebih terarah.

Sistematika sintaks yang dikaji dalam penelitian ini terkait dengan susunan/sistematika sintaks yang dibuat oleh kelompok mahasiswa. Sintaks yang dirancang oleh kelompok mahasiswa harus jelas dan berurutan (sistematik), hal ini akan mempermudah untuk memahami langkah-langkah dalam pembelajaran secara keseluruhan. Kemampuan mahasiswa dalam menyusun sintaks secara sistematis dapat dikatergorikan baik yaitu sebesar 64,21\%. Aspek sistematika sintaks ini merupakan aspek terendah Dengan demikian sintaks pembelajaran yang dikembangkan oleh kelompok mahasiswa tidak tersusun dengan baik dan sistematis, hal ini yang harus menjadi fokus dalam program perkuliahan. Hal tersebut sejalan dengan pendapat Rustaman (2000) apabila dalam pembelajarannya seorang guru menggunakan tahap-tahap pembelajaran, tahaptahapnya harus tertentu dan jelas. Sistem sosial dan sistem pendukungnya harus dirancang dengan baik, karena kelas di dalam sekolah merupakan bagian dari sistem sosial.

Integrasi etnopedagogi dalam pengembangan model pembelajaran dimaksudkan adalah seberapa besar unsur budaya yang terdapat dalam model pembelajaran yang dikembangkan. Integrasi etnopedagogi sebesar $84,87 \%$, menjelaskan bahwa model pemebelajaran yang dikembangkan yang berorientasi etnopedagogi oleh mahasiswa tergolong baik dan sebagian besar terdapat unsure etnopedagogi dalam sintaksnya. Hal ini dapat dipahami karena sebagian besar mahasiswa berasal dari tatar sunda, sehingga nilai-nilai budaya sunda melekat pada diri mahasiswa. Hal ini tentu saja memberikan efek terhadap model pembelajaran yang dibuat karena sesuai dengan apa yang mereka alami dan peroleh dalam kehidupan sehari-hari khususnya terkait dengan tradisi, adat istiadat dan pola kehidupan masyarakat sunda. Hal ini didukung oleh pendapat yang dikemukakan oleh Kosasih (t.t:6) melalui kebudayaan, manusia membina interaksi dengan sesamanya, dengan alam, serta mewariskan nilai-nilai yang dianggap bermanfaat bagi kelangsungan hidup mereka dari generasi ke generasi. Hal itu berarti bahwa kebudayaan secara langsung ataupun tidak langsung, mampu memberikan identitas tertentu bagi individu dan masyarakat pendukungnya.

Kreatifitas pengembangan model dalam penelitian ini dimaksudkan sejauh mana mahasiswa dapat berkreasi dengan mengkolaborasikan model pembelajaran yang mereka kembangkan dengan unsur etnopedagogi. Kreatifitas mahasiswa cukup baik yaitu sebesar 73,82\%. Meskipun kreatifitas mahasiswa tergolong cukup baik dalam mengembangkan model pembelajaran, namun aspek kreatifitas mahasiswa tergolong paling rendah dibandingkan dengan aspek-aspek yang lain. Hal ini dapat dimengerti karena sebuah kreatifitas tidak akan muncul dengan mudah begitu saja, mungkin hanya orang-orang tertentu yang memiliki kreatifitas yang tinggi. Hal ini didukung oleh pendapat yang dikemukakan oleh Sanjaya (2005) dapat dipastikan bahwa hanya individu yang mampu bersaing yang akan berbicara dalam era globalisasi, untuk itu setiap individu harus memiliki kompetensi yang handal dalam berbagai bidang sesuai dengan minat, bakat dan kemampuan nyata. Selain itu mahasiswa yang terlibat dalam penelitian ini mungkin telah beradaptasi dengan lingkungan dengan teknologi yang maju, hidup ditengah-tengah akulturasi budaya, sehingga mereka kurang memahami bagaimana nilai budaya daerah harus mereka tuangkan dalam model pembelajaran. pada akhirnya hal ini mengakibatkan kreatifitas mahasiswa menjadi terbatas. Hal serupa dikemukakan oleh Kosasih (t.t.) Anak-anak tempo dulu sangat tertantang oleh alam dan lingkungan hidupnya berada. Mereka mampu memanfaatkan apa yang ada di lingkungannya. Sebagai akibatnya, mereka harus kreatif, selalu siap menghadapi tantangan dan rintangan yang muncul setiap saat.

Kemampuan kelompok mahasiswa calon guru dalam mengambangkan model pembelajran biologi berbasis etnopedagogi termasuk dalam kategori cukup. Dengan demikian kemampuan pengembangan model pembelajaran biologi pada mahasiswa calon guru harus terus dikembangkan. Hal ini cukup dimengerti karena model pembelajaran yang dikembangkan cukup sulit karena didalamnya harus terkait model pembelajaran, pembelajaran biologi dan etnopedagogi. Hal senada dikemukakan oleh Dahar (1989) model merupakan suatu analog konseptual yang digunakan untuk menyarankan bagaimana meneruskan penelitian empiris sebaiknya 
tentang suatu masalah. Hal ini dimaksudkan bahwa pengembangan model pembelajaran harus secara kontinu terutama melalui berbagai penelitian, sehingga nantinya akan muncul sebuah model yang tepat dan dapat diterapkan dalam pembelajaran dan dapat dijadikan solusi dalam masalah pendidikan khususnya di Indonesia. Sejalan dengan pendapat yang dikemukakan oleh Arikunto (2003) di dalam melaksanakan kegiatan belajar mengajar mungkin saja guru menjumpai kesulitan sehubungan dengan keadaan siswa, maka dari itu guru harus memilih yang paling tepat. Mengembangkan sebuah model pemebelajaran tidaklah mudah karena banyak kriteria atau aspek-aspek tertentu yang harus dipahami oleh mahasiswa. Model pembelajaran inovatif yang dibuat harus menunjukan efektifitas dalam pembelajaran dan memperhatikan beberapa aspek kunci serta tujuan yang ingin dicapai. Sejalan dengan hal tersebut Krell, et al. (2015), Cil, et al. (2016) dan Costa, et al. (2016) menyatakan bahwa penggunaan model pembelajaran harus menjadi aspek kunci dalam kegiatan pembelajaran dan implikasinya dalam pendidikan terutama oleh calon guru untuk menemukan cara baru dalam mengajar. Dalam hal ini mahasiswa harus memahami aspek kunci dalam mengembangkan sebuah model pembelajaran, aspek kunci tersebut tentu saja harus relevan dengan tujuan pembelajaran, kebutuhan siswa dalam pembelajaran dan penilaian. Selain itu Marsh (1996), Dahar (1989), Sa'ud (2008) dan Sanjaya (2005) menyatakan bahwa guru harus memiliki kompetensi mengajar, memotivasi peserta didik, membuat model instruksional, mengelola kelas, berkomunikasi, merencanakan pembelajaran, dan mengevaluasi yang mengarah pada penelitian sebagai cikal bakal adanya inovasi sehinga dapat bersaing di era globalisasi. Hal ini menjelaskan bahwa dalam mengembangkan sebuah model pembelajaran seorang mahasiswa calon guru haru memliki kompetensi dalam segala hal menyangkut pembelajaran. Kesulitan dalam mengembangkan model pembelajaran dikemukakan oleh Eggen dan Kauchak (2012) berpendapat bahwa model pembelajaran harus didukung oleh teori dan penelitian tentang pembelajaran dan motivasi. Dengan demikian mengembangkan sebuah model pembelajaran harus memiliki dasar teori yang jelas dan alangkah lebih baiknya model pembelajaran yang dikembangkan berdasarkan pada beberapa hasil penelitian. Banyak aspek atau kriteriakriteria khusus yang harus dipenuhi dalam mengembangkan sebuah model pembelajaran, untuk itu Joyce dan Weil (2000) berpendapat bahwa model pembelajaran harus meliputi beberapa aspek diantaranya sintaks yang jelas, harus menggambarkan sistem sosial sebagai bentuk interaksi, sistem reaksi berupa penilaian, sistem pendukung yang selalu menjadi bagian penting dalam keterlaksanaan model pembelajaran dan dampak terhadap pembelajaran khususnya dampak positif bagi siswa.

Berdasarkan hasil analisis kuesioner tanggapan mahasiswa persentase tertinggi pada pernyataan nomor 1 sebesar $86,67 \%$. Pernyataan tersebut menjelaskan bahwa model pembelajaran biologi sangat perlu dikembangkan seiring dengan perkembangan jaman. Hal ini menunjukan bahwa 86,67\% mahasiswa menganggap bahwa model-model yang ada khususnya untuk pembelajaran biologi harus dikembangkan dalam hal ini diperlukan inovasi-inovasi baru yang lebih mutakhir seiring dengan perkembangan jaman. Persentase pernyataan terendah yaitu pada pernyataan nomor 13 sebesar 57,75\%. Pernyataan tersebut menjelaskan bahwa mahasiswa merasa kesulitan dalam mengembangkan pembelajaran biologi berbasis etnopedagogi. Hal ini menunjukan bahwa sebanyak 57,75\% mahasiswa merasa kesulitan dalam mengembangkan model pembelajaran berbasis etnopedagogi, hal ini dapat dipahami karena pengembangan model berbasis etnopedagogi merupakan hal baru bagi mereka dan ruang lingkupnya terbatas, sehingga mahasiswa tidak leluasa dalam mengembangkan model pembelajaran sesuai dengan apa yang mereka kehendaki. Tetapi jika kita kaji angka tersebut cukup seimbang, berarti sebanyak 42,25\% mahasiswa dapat mengembangkan model pembelajaran berbasis etnopedagogi dengan mudah tanpa mengalami kesulitan.

\section{SIMPULAN DAN SARAN}

Mahasiswa calon guru harus memiliki kemampuan dalam mengembangkan model pembelajaran yang mana akan bermanfaat pada saat menjadi seorang kelak. Model pembelajaran dapat menjadi sebuah pedoman dalam proses pembelajaran, dpat pula menentukan keberhasilan. Hasil penelitian ini menunjukan bahwa kemapuan mahasiswa calon guru biologi dalam mengembangkan model pembelajaran berorientasi etnopedagogi termasuk dalam kategori cukup. Sebagian besar mahasiswa mendukung pengembangan model 
pembelajaran dengan mengintegrasikan unsur etnopedagogi didalamnya. Namun, mahasiswa merasa kesulitan dalam mengintegrasikannya ke dalam sistematika sintaks yang mereka rancang. Tentu saja hal ini harus mendapat perhatian khusus dalam upaya pengembangan program perkuliahan yang akan dating.

Simpulan disajikan dalam bentuk esai bukan dalam bentuk numerical. Saran disusun berdasarkan Simpulan yang telah ditarik. Saran-saran bisa mengacu pada tindakan praktis, atau pengembangan teoritis, dan penelitian lanjutan. Bagian saran bisa berdiri sendiri. Bagaian simpulan dan saran dapat pula disebut bagian penutup

\section{DAFTAR RUJUKAN}

Arikunto, S. (2003). Dasar-Dasar Evaluasi Pendidikan. Edisi Revisi. Jakarta: Bumi Aksara.

Dahar, R. W. (1989). Teori-teori Belajar. Bandung: Erlangga.

Cil, E., et al. (2016). Design, implementation and evaluation of innovative science teaching strategies for nonformal learning in a natural history museum. Research in Science \& Technological Education, 2016. http://dx.doi.org/10.1080/02635143.2016.1222360.

Costa, A., et al. (2016). Partners in learning and innovative teaching practices. An approach to conservation education to suit the context and purpose of learning skills in the 21st century: a pilot study. Int. Zoo Yb. V. 50: 125-128. DOI:10.1111/izy.12122 .The Zoological Society of London.

Eggen, P. \& Kauchak, D. (2012). Strategies and Models for Teachers. $6^{\text {th }}$ Edition. Boston: Pearson Inc.

Joyce, B., Weil, M. \& Calhoun, E. (2000). Models of Teaching. $6^{\text {th }}$ Edition. Boston: Allyn and Bacon.

Jumadi (2012). Pemetaan Kompetensi Pedagogik, Profesional, Kepribadian dan Sosial Guru Fisika SMA/MA di Daerah Istimewa Yogyakarta. (Makalah). LPPKM UNY. Tidak diterbitkan.

Kosasih, D. (t.t.). Etnopedagogi dalam Kaulinan dan Kakawihan Barudak Sunda. Makalah disampaikan pada "Konperensi Nasional dan Pembentukan Organisasi Profesi Pengajar Bahasa, Sastra dan Budaya Daerah Se-Indonesia” Tanggal 8-9 di Kaliurang Jogja.

Krell, M., et al. (2015). Testing Models: A Key Aspect to Promote Teaching Activities Related to Models and Modelling in Biology Lessons?. Journal of Biological Education, 2015. http://dx.doi.org/10.1080/00219266.2015.1028570

Marsh, C. (1996). Handbook for Beginning Teachers. Sydney: Addison Wesley Longman Australia Pry Limited.

Mudjiman, H. (2009). Belajar Mandiri (Self-motivated Learning). Surakarta: UNS Press.

Prawoto. (1992). Pemahaman Guru-guru Biologi SMA Kota Madya Yogyakarta Terhadap Strategi Belajar Mengajar (Makalah). Yogyakarta: IKIP Yogyakarta

Rustaman, N. (2000). Arah Pendidikan Biologi Pra-Univesitas di Indonesia. Makalah Simposium Biologi dalam Seminar Nasional Biologi XVI dan Kongres Nasional Perhimpunan Biologi Indonesia XV. Institut Teknologi Bandung.

Rustaman, N. (2005). Strategi Belajar Mengajar Biologi. Malang: Universitas Negeri Malang.

Sanjaya, W. (2005). Pembelajaran Dalam Implementasi Kurikulum Berbasis Kompetensi. Edisi Pertama. Jakarta: Prenada Media

Sa’ud, U. S. (2008). Inovasi Pendidikan. Bandung: Alfabeta. 
Sugiyono. (2011). Metode Penelitian Pendidikan. Pendekatan Kuantitatif, kualitatif dan R\&D. Bandung: Alfabeta.

Suratno, T. (2010). Memaknai Etnopedagogi Sebagai Landasan Pendidikan Guru di Universitas Pendidikan Indonesia. Proceedings of The 4th International Conference on Teacher Education; Join Conference UPI \& UPSI Bandung, Indonesia, 8-10 November 2010

Zaltman, G., Duncan, R. \& Holbek, J. (1973). Innovation and Organization. A Wiley-Interscience Publication John Wiley and Sons, New York. London, Sidney, Toronto. 